\title{
Cerrahi Girişim Geçiren Yaşlı Hastalarda Bilişsel Fonksiyon Bozukluğunun Değerlendirilmesi
}

\author{
Sevim Çelik, Duygu Kavacık, Asude Nair, Nurdan Şeker, Leyla Demirel \\ Bülent Ecevit Üniversitesi Zonguldak Sağlık Yüksekokulu Hemşirelik Bölümü, Zonguldak
}

\begin{abstract}
ÖZET
Cerrahi girişim geçiren yaşlı hastalarda bilişsel fonksiyon bozukluğunun değerlendirilmesi

Amaç: Bu çalışmanın amacı cerrahi girişim geçiren yaşlı hastalarda bilişsel fonksiyon bozukluğunun görülme sıklığını ve etkileyen faktörleri belirlemektir.

Gereç ve Yöntem: Çalışma, ileriye dönük tanımlayıcı ve ilişki arayıcı çalışma olarak dizayn edildi. 36 hasta ile ameliyat öncesi, ameliyat sonrası 1. gün ve 3. günde görüşme yapıldı. Veriler, Kişisel Bilgi Formu, cerrahi girişim sonrası 1. ve 3. günündeki bilişsel değişiklikleri değerlendiren Mini Mental Durum Testi ve hasta bilgi dosyası kullanılarak toplandı.

Bulgular: Ameliyat öncesi dönemde hastaların \%91.6'sının bilişsel fonksiyonları normaldi. Ameliyat sonrası 1. günde hastaların \%47.2'sinin, ameliyat sonrası 3. günde \%33.4'ünün bilişsel fonksiyonları bozulmuştu. Genel anestezi alan hastaların bilişsel fonksiyonlarda ameliyat sonrası 1. günde anlamlı şekilde bozulma mevcuttu ( $\mathrm{p}=0.04)$. Yaş artışı ile bilişsel fonksiyon bozukluğu arasında anlamlı ilişki vardı $(\mathrm{p}=0.00)$. Kadınların ameliyat sonrası bilişsel fonksiyonlarında anlamlı değişiklikler gözlendi $(\mathrm{p}=0.00)$.
\end{abstract}

Sonuç: Bu çalışma, yaşılı hastaların ameliyat sonrası bilişsel fonksiyonlarında anlamlı bozulma olduğunu gösterdi.

Anahtar kelimeler: Yaşılı hasta, ameliyat sonrası dönem, bilişsel fonksiyon

\begin{abstract}
Evaluation of cognitive dysfunction in elderly patients undergoing surgery

objective: The aim of this study was to identify the incidence of cognitive impairment in elderly patients who underwent surgery and affecting factors.

Material and Methods: The study was designed as a prospective and correlational study. It was interviewed with 36 patients on preoperative period, on postoperative day 1 and day 3. Data were collected by personal information form, Mini Mental State Examination and patient information file.

Results: $91.6 \%$ of patients with preoperative cognitive function were normal. Of up to $47.2 \%$ of patients on postoperative day 1 , in $33.4 \%$ of patients on postoperative day 3 , cognitive function was impaired. There was significant deterioration on cognitive functions of the patients who received general anesthesia $(\mathrm{p}=0.04)$. There was a significant relationship between cognitive impairment and increasing age $(\mathrm{p}=0.00)$. Significant changes in postoperative cognitive function of women was observed $(p=0.00)$.

Conclusion: This study showed significant deterioration on cognitive functions of elderly patients in the post-operative period.

Key words: Elderly patient, postoperative period, cognitive function
\end{abstract}

Bakırköy Tıp Dergisi 2015;11:66-73

\section{Giriş}

Y aşlılık; kompleks zihinsel aktiviteler olarak tanımlanan bilişsel yeteneklerin azalmaya başladığı, fiziksel fonksiyonların düştüğü ve normal yaşam süresinin son

Yazışma adresi / Address reprint requests to: Sevim Çelik Bülent Ecevit Üniversitesi, Zonguldak Sağılı Yüksekokulu Hemşirelik Bölümü, Zonguldak

Telefon / Phone: +90-372-261-33-4243

Elektronik posta adresi / E-mail address: sevimakcel@yahoo.com

Geliş tarihi / Date of receipt: 26 Eylül 2014 / September 26, 2014

Kabul tarihi / Date of acceptance: 17 Kasım 2014 / November 17, 2014 evresine geçiş sürecidir. Bu süreçte yaşlıların teknolojik ilerlemelere bağlı olarak değişik sağlık sorunları nedeniyle cerrahi girişim deneyimleme sıklıkları artmaktadır $(1,2)$. Cerrahi girişim geçiren yaşlı hastalarda erken ameliyat sonrası dönemde gelişebilecek komplikasyonlar diğer yaş gruplarındaki hastalar ile benzer olmakla birlikte, yaşlıların bilişsel değişiklikleri deneyimleme oranı daha fazladır $(2,3)$. Bu oranın majör cerrahi girişim geçiren hastalarda \%20-90 arasında değiştiği bildirilmektedir. Bilişsel fonksiyon değişiklikleri yaşlı hastalarda ameliyat sonrası çeşitli komplikasyonların ve hastanede kalış süresinin artışında doğrudan ilişkili olan önemli bir sağlık problemidir (3-5). 
Ameliyat sonrası yaşlı hastalarda bilişsel fonksiyon değişikliğinin patolojik mekanizması hala açık değildir, fakat çok çeşitli nedenlerin etkili olduğu bildirilmektedir. Bir görüşe göre, ameliyat sırasında oluşan mikroembolilerin beyine geçmesinden, genel anestezi ve ameliyat sonrası uygulanan analjeziden kaynaklanabileceği bildirilmektedir (5-9). Ayrıca ameliyat öncesi yaşanan fonksiyonel veya bilişsel bozuklukları, perioperatif süreç, hareketsizlik veya uygunsuz fiziksel koşullar, uyku eksikliği, görsel veya fiziksel bozukluk, dehidratasyon, hipoksi, hiperkapni, hipotansiyon, hiperglisemi, dengesiz beslenme, elektrolit dengesizliği, kan kaybı, depresyon, antikolinerjik ilaç tedavisi, alkol bağımlıı̆ı ve eğitim eksikliği gibi pek çok faktörün risk oluşturacağı üzerinde durulmaktadır (1,4,10-12).

$\mathrm{Bu}$ araştırma; cerrahi girişim geçiren yaşı hastalarda bilişsel fonksiyon bozukluğunun görülme sıklığını, hastaların demografik özelliklerinin ve cerrahi girişim sürecine ilişkin özelliklerinin bilişsel fonksiyon bozukluklarına etkisini belirlemek amacıyla yapıldı.

\section{GEREÇ VE YÖNTEM}

Bu araştırma Bülent Ecevit Üniversitesi Sağlık Uygulama ve Araştırma Merkezi'ndeki hastalar ile ileriye dönük tanımlayıcı ve ilişki arayıcı nitelikte çalışma olarak yapıldı. Araștırmanın uygulanabilmesi için Bülent Ecevit Üniversitesi Klinik Araştırmalar Etik Kurul'undan (2014/3-7 nolu karar) ve Sağlık Uygulama ve Araştırma Merkezi'nden yazılı onay alındı. Hastalardan bilgilendirilmiş yazılı onay alındı.

Şubat-Mayıs 2014 tarihleri arasında genel cerrahi, ortopedi ve üroloji servislerinde yatan hastalar araştırmanın evrenini oluşturdu. Araştırma; araştırmaya katılmayı kabul eden, 65 yaş ve üzerinde olan, cerrahi girişim sonrası en az 3 gün süre ile bu servislerde yatan, iletişim sorunu olmayan, Türkçe bilen ve anlayan, görme ve işitme problemi olmayan, ameliyat öncesi süreçte tanılanmış psikiyatrik problemi olmayan, ameliyat öncesi süreçte en az bir gün süreyle hastanede yatan, alkol bağımlığı bulunmayan, genel ve bölgesel anestezi ile ameliyat geçirmiş olan, acil cerrahi girişim geçirmeyen, kabulde ve ameliyat sonrası dönemde bilinci açık, 36 yaşlı hasta ile gerçekleştirildi. Ameliyat sonrası dönemde 3. günden önce taburcu olan ve araştırmaya katılmak istemeyen toplam 13 hasta örneklem dışı bırakıldı.

Veriler, Kişisel Bilgi Formu, cerrahi girişim sonrası 1. ve
3. günündeki bilişsel değişiklikleri değerlendiren Mini Mental Durum Testi ve hasta bilgi dosyası kullanılarak toplandı. Tanıtım Formu konu ile ilgili literatür doğrultusunda araştırmacılar tarafından oluşturuldu (2,13-17). Birinci bölümde; hastaların yaşı, cinsiyeti, medeni durumu, sigara içme durumu, alkol kullanma durumu, sağlık güvencesi, gelir durumu, birlikte yaşadığı kişiler, çalışma durumu, uyku alışkanlığı, kronik hastalıklar, sürekli kullandığı ilaçlar, cerrahi tipi, cerrahi süresi, ameliyat öncesi dönemde kullanılan analjezikler, ameliyat sonrası dönemde kullanılan analjezikleri değerlendiren 17 kapall uçlu soruya yer verildi. íkinci bölümde; ameliyat öncesi ve sonrası dönemde sodyum, hematokrit, total bilirubin, hipoalbuminemi, BUN/kreatinin, hipo/hiperglisemi, kan transfüzyonu, immobilizasyon, yoğun bakım ünitesinde kalış süresini değerlendiren 10 açık uçluya yer verildi.

Mini Mental Durum Testi (MMT) yaşlı hastalarda gelişen bilişsel değişiklikleri izlemek amacı ile geliştirilmiş değerlendirme testidir. 1975 yllında Folstein ve arkadaşları tarafından geliştirilen bu kısa tarama testi, demans taraması için en sık kullanılır (18). On bir sorudan oluşur ve 30 puan üzerinden değerlendirilir. 24-30 puan arası normal,18-23 puan arası hafif demans, 17 puan ve alt ciddi demansla uyumludur. Oryantasyon, hafıza, dikkat, hesaplama, hatırlama, lisan, motor fonksiyon ve algılama yetenekleri test eder. MMT'nin test tekrar test geçerliliği 0.56-0.98 olarak bildirilmiştir. Türkiye'deki geçerlilik ve güvenilirliği Güngen ve arkadaşları tarafından 2002 yılında yapılmıştır (19). Testin eşik değerler için 23/24 değerinin 0.91 duyarlık, 0.95 özgüllük, sırasıyla 0.90, 0.95 ve 0.86 pozitif, negatif yordayıcı değer ile kappa değeri gösterdiği saptanmıştır. Uygulayıcılar arası güvenilirlik incelemesinde r:0.99, kappa değeri ise 0.92 olarak elde edilmiştir.

Hasta Bilgi Dosyası; hasta dosyasındaki hemşire ve hekim izlem formlarından, ameliyat raporlarından hastalara uygulanan ameliyatlar, ameliyat şekli, kullanılan ilaçlar ve laboratuvar değerleri hakkında bilgi alındı.

Ameliyat sonrası süreçte bilişsel değişikliğe etkisi olabileceği düşünülen bireysel özellikler ve MMT ile ilgili veriler, hastalar ile ameliyat öncesi ve ameliyat sonrası 1 ve 3. günlerde görüşülerek toplandı. Ameliyat öncesinde bireysel özelliklerine ilişkin form dolduruldu ve MMT uygulandı. Ameliyat sonrası 1. ve 3. günde ise sadece MMT uygulandı. Hastalar ile her biri ortalama 10dk. süren 3 görüşme gerçekleştirildi. Görüşmeler gürültüden uzak ve daha rahat bir ortam olması amacıyla akşam 18:00 19:00 saatleri arasında yapıldı. 
Verilerin değerlendirilmesinde SPSS 16.0 programı kullanıldı. Tanımlayıcı istatistiksel yöntemlerin yanı sıra, tek grupta ameliyat öncesi ve sonrası parametrik değerlerin karşılaştırılmasında eşlendirilmiş dizilerde t testi, ameliyat öncesi, ameliyat sonrası 1.gün ve 3 . gün bilişsel fonksiyon değişikliklerinin karşılaştırılmasında tekrarlayıCl ölçümlerde varyans analizi, tek grupta ameliyat öncesi ve sonrası nonparametrik değerlerin karşılaştırılmasında ki-kare testi kullanıldı. íki grup ortalamaları arasındaki farkın incelenmesinde Mann Whitney U testi, üç ve üzeri gruplarda Kruskal-Wallis testi kullanıldı. Sayısal değişkenlerin birbirleriyle ilişki derecesinin belirlenmesinde Pearson Korelasyon testi kullanıldı. Anlamlılık $p<0.05$ düzeyinde değerlendirildi.

\section{BULGULAR}

Hastaların \%52.8'inin erkek, \%94.4'ünün evli ve \%5.6'sının sigara içme alışkanlığının olduğu; hiçbirinin alkol kullanmadığı saptandı. \%97.2'sinin eşi ile birlikte yaşadığı; hiçbirinin aktif olarak çalışmadığı; \%22.2'sinin gelirinin giderinden az olduğu belirlendi. Ayrıca \%25'inin gece uyku süresinin 6 saatten az sürdüğü; \%30.6'sının diyabet hastalığı olduğu ve en sık \%30.6 gibi eşit oranlarda beta-bloker ve anti-trombolitik ilaç kullandıkları belirlendi saptandı (Tablo 1).

Hastaların ameliyat öncesi dönemde \%91.6'sının bilişsel fonksiyonları normal iken, ameliyat sonrası 1. günde \%47.2'sinin, ameliyat sonrası 3. günde de \%33.4'ünün bilişsel fonksiyonlarında bozulma olduğu bulundu. Hastaların MMT'den ameliyat öncesi dönemde ortalama $27.66 \pm 3.20$, ameliyat sonrası 1 . günde $21.77 \pm 8.00$ ve ameliyat sonrası 3. günde $24.91 \pm 4.49$ puan aldıkları saptandı.
Ameliyat öncesi test puanlarının istatistiksel olarak da anlamlı şekilde ameliyat sonrası dönemde düştüğü $(\mathrm{p}=0.00$ ) belirlendi (Tablo 2).

Tablo 1: Hastaların bireysel özellikleri

\begin{tabular}{|c|c|c|}
\hline & Mean \pm SD & Min-Max \\
\hline \multirow[t]{2}{*}{ Yaş } & $68.58 \pm 5.33$ & $65-86$ \\
\hline & $\mathrm{n}$ & $\%$ \\
\hline \multicolumn{3}{|l|}{ Cinsiyet } \\
\hline Erkek & 19 & 52.8 \\
\hline Kadın & 17 & 47.2 \\
\hline \multicolumn{3}{|l|}{ Medeni durum } \\
\hline Evli & 34 & 94.4 \\
\hline Bekar & 2 & 5.6 \\
\hline \multicolumn{3}{|l|}{ Sigara içme alışkanlığı } \\
\hline Evet & 2 & 5.6 \\
\hline Hayır & 34 & 94.4 \\
\hline \multicolumn{3}{|l|}{ Birlikte yaşadığı kişiler } \\
\hline Yalnız & 1 & 2.8 \\
\hline Eşi ve çocukları & 35 & 97.2 \\
\hline \multicolumn{3}{|l|}{ Çalışma durumu } \\
\hline Çalışıyor & 0 & 0.0 \\
\hline Çalışmıyor & 36 & 10.0 \\
\hline \multicolumn{3}{|l|}{ Gelir durumu } \\
\hline Gelir giderden az & 8 & 22.2 \\
\hline Gelir gidere eşit & 27 & 75.0 \\
\hline Gelir giderden fazla & 1 & 2.8 \\
\hline \multicolumn{3}{|l|}{ Gece uyku alışkanlığı } \\
\hline 6 saatten az & 9 & 25.0 \\
\hline 6-8 saat & 22 & 61.1 \\
\hline 8 saatten fazla & 5 & 13.9 \\
\hline \multicolumn{3}{|l|}{ Kronik hastalıkları } \\
\hline Diyabet & 11 & 30.6 \\
\hline Kalp yetmezliği & 13 & 36.1 \\
\hline Hipertansiyon & 18 & 50.0 \\
\hline \multicolumn{3}{|l|}{ Sürekli kullandığı ilaçlar } \\
\hline Betabloker & $11^{*}$ & $30.6^{* *}$ \\
\hline Antitrombolitik & $11^{*}$ & $30.6^{* *}$ \\
\hline Antiepileptik & $1^{*}$ & $2.8^{* *}$ \\
\hline Kalsiyum kanal blokeri & $5^{*}$ & $13.9^{* *}$ \\
\hline Proton pompası inhibitörü & $4^{*}$ & $11.1^{* *}$ \\
\hline Antidiyabetik & $10^{*}$ & $27.8^{* *}$ \\
\hline
\end{tabular}

*Birden fazla yanıt verilmiştir. ${ }^{* *}$ Yüzdeler n (36) sayısına göre alınmıştır.

Tablo 2: Hastaların MMT puan ortalamaları

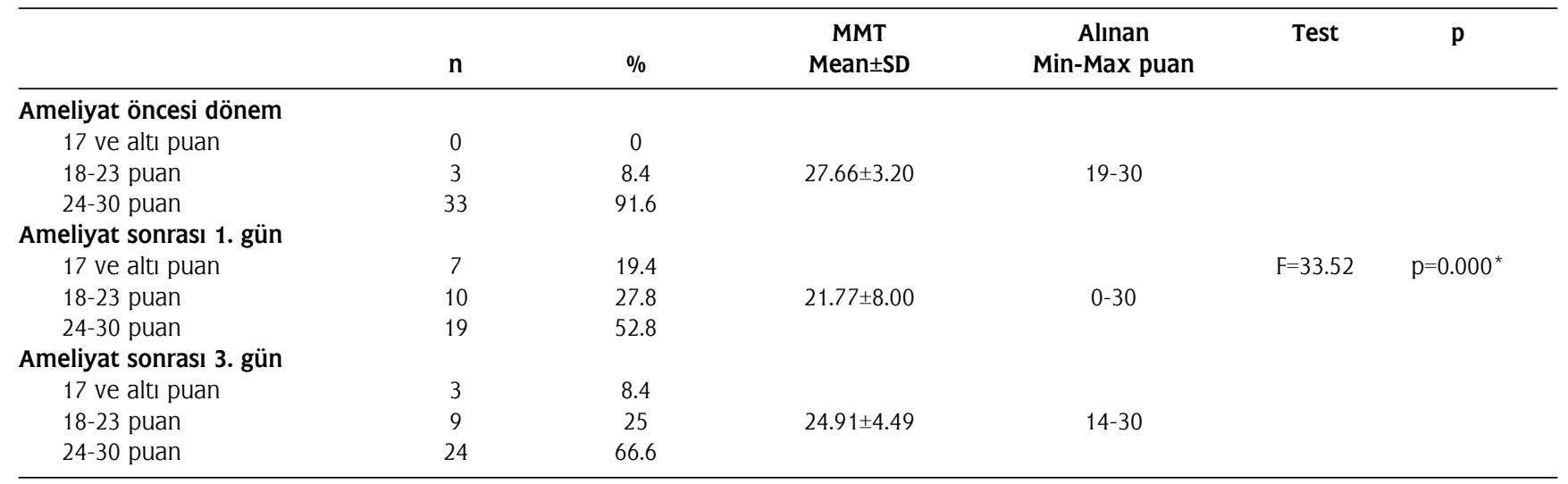

\footnotetext{
${ }^{*} \mathrm{p}<0.05$
} 
Tablo 3: Hastaların kullandıkları analjezikler ile MMT puan ortalamalarının karşılaştırılması

\begin{tabular}{|c|c|c|c|c|c|c|c|}
\hline & \multicolumn{3}{|c|}{ Ameliyat Öncesi } & \multicolumn{3}{|c|}{ Ameliyat Sonrası } & \multirow[b]{2}{*}{$\begin{array}{c}\text { MMT } \\
\text { 3.gün } \\
\text { Mean } \pm \text { SD }\end{array}$} \\
\hline & $\mathrm{n}$ & $\%$ & $\begin{array}{c}\text { MMT } \\
\text { Mean } \pm \text { SD }\end{array}$ & $\mathrm{n}$ & $\%$ & $\begin{array}{c}\text { MMT } \\
\text { 1. gün } \\
\text { Mean } \pm \text { SD }\end{array}$ & \\
\hline \multicolumn{8}{|l|}{ Opioid } \\
\hline Evet & 2 & 5.6 & $24.50 \pm 7.77$ & 20 & 55.6 & $21.55 \pm 8.41$ & $25.30 \pm 4.06$ \\
\hline Hayır & 34 & 94.4 & $27.85 \pm 2.90$ & 16 & 44.4 & $22.06 \pm 7.72$ & $24.43 \pm 5.07$ \\
\hline$Z \quad p$ & & & $\begin{array}{ll}-0.67 & 0.50\end{array}$ & & & $\begin{array}{ll}-0.80 & 0.93\end{array}$ & $\begin{array}{ll}-0.35 & 0.72\end{array}$ \\
\hline Hayır & 23 & 63.9 & $27.95 \pm 2.85$ & 28 & 77.8 & $21.14 \pm 8.24$ & $25.07 \pm 3.99$ \\
\hline Z & & & $-3.32 \quad 0.74$ & & & $-1.14 \quad 0.25$ & $\begin{array}{ll}-0.01 & 0.98\end{array}$ \\
\hline \multicolumn{8}{|c|}{ Analjezik etkili parasetamol } \\
\hline Evet & 8 & 22.2 & $28.37 \pm 2.50$ & 4 & 11.1 & $23.75 \pm 2.06$ & $27.25 \pm 2.36$ \\
\hline Hayır & 28 & 77.8 & $27.46 \pm 3.39$ & 32 & 88.9 & $21.53 \pm 8.45$ & $24.62 \pm 4.63$ \\
\hline $\mathrm{p}$ & & & $-0.53 \quad 0.59$ & & & $-0.10 \quad 0.92$ & $\begin{array}{ll}-0.88 & 0.37\end{array}$ \\
\hline
\end{tabular}

Araştırmada hastaların \%64.4'ünün ameliyat öncesi dönemde analjezik kullandıkları ve bu analjeziklerden en sık olarak non-steroidal antienflamatuar ilaçları (\%36.1) kullandıkları saptandı. Ameliyat sonrası dönemde de hastaların \%88.9'unun analjezik kullandıkları ve bu dönemde de kullanılan analjeziğin en sık opioid analjezikler olduğu belirlendi. Hastaların kullandıkları analjezikler ile MMT puan ortalamaları arasında anlamlı farklılık oluşmadığı saptandı. Opioid kullanan hastalarda ameliyat öncesi, ameliyat sonrası 1. ve 3. günlerde MMT puan ortalamalarının düştüğü belirlendi (Tablo 3).

Tablo 4'de hastaların cerrahi girişim sürecine ilişkin özelliklerinin dağlımına yer verildi. Bu tabloya göre; hastaların cerrahi girişim sürelerinin ortalama $3.18 \pm 1.52$ saat olduğu, \%63.9'unun açık cerrahi girişim ve \%52.8'inin ortopedik cerrahi girişim geçirdiği belirlendi. Hastaların \%36.1'ine ameliyat öncesi dönemde \%22'sine de ameliyat sonrası dönemde kan transfüzyonu yapıldığı, \%86.1'inin ameliyat öncesi dönemde mobil iken ameliyat sonrası \%94.4'ünün mobil olduğu, \%13.9'unun ameliyat öncesi ve \%11.1'inin de ameliyat sonrası yoğun bakım ünitesinde yattıkları belirlendi (Tablo 4).

Hastaların cerrahi girişim sürecine ilişkin özellikleri ile ameliyat öncesi, ameliyat sonrası 1.gün ve 3. gün MMT puan ortalamaları arasında istatistiksel anlamlı farklılık ve ilişki saptanmadı. Aynı tabloda; kapalı cerrahi girişim geçirenlerin, kan transfüzyonu yapılmayanların, ameliyat öncesi mobil olanların, ameliyat sonrası immobil olanların MMT puan ortalamalarının her üç günde de diğerlerine göre daha yüksek olduğu bulundu. Uygulanan cerrahi girişimin bilişsel fonksiyonları etkilemediği, ürolojik cerrahi girişim geçiren hastaların ameliyat sonrası dönemde MMT puan ortalamalarının normal sınırlarda olduğu belir-
Tablo 4: Hastaların cerrahi girişim sürecine ilişkin özellikleri

\begin{tabular}{|c|c|c|c|c|}
\hline & \multicolumn{2}{|c|}{ Mean \pm SD } & \multicolumn{2}{|c|}{ Min-Max } \\
\hline Cerrahi süresi (saat) & \multicolumn{2}{|c|}{$3.18 \pm 1.52$} & \multicolumn{2}{|c|}{$0.50-6$} \\
\hline & \multicolumn{2}{|c|}{$\mathrm{n}$} & \multicolumn{2}{|c|}{$\%$} \\
\hline \multicolumn{5}{|l|}{ Cerrahi yöntemi } \\
\hline Açık & \multicolumn{2}{|c|}{23} & \multicolumn{2}{|c|}{63.9} \\
\hline Kapalı & \multicolumn{2}{|c|}{13} & \multicolumn{2}{|c|}{36.1} \\
\hline \multicolumn{5}{|l|}{ Anestezinin tipi } \\
\hline Genel & \multicolumn{2}{|c|}{18} & \multicolumn{2}{|c|}{50} \\
\hline Bölgesel & \multicolumn{2}{|c|}{18} & \multicolumn{2}{|c|}{50} \\
\hline \multicolumn{5}{|l|}{ Cerrahi tipi } \\
\hline Ortopedik cerrahi & \multicolumn{2}{|c|}{19} & \multicolumn{2}{|c|}{52.8} \\
\hline Ürolojik cerrahi & \multicolumn{2}{|c|}{10} & \multicolumn{2}{|c|}{27.8} \\
\hline \multirow[t]{3}{*}{ Genel cerrahi } & \multicolumn{2}{|c|}{7} & \multicolumn{2}{|c|}{19.4} \\
\hline & \multicolumn{2}{|c|}{$\begin{array}{l}\text { Ameliyat } \\
\text { Öncesi }\end{array}$} & \multicolumn{2}{|c|}{$\begin{array}{l}\text { Ameliyat } \\
\text { Sonrası }\end{array}$} \\
\hline & $\mathrm{n}$ & $\%$ & $\mathrm{n}$ & $\%$ \\
\hline \multicolumn{5}{|l|}{ Kan transfüzyonu } \\
\hline Yapıldı & 13 & 36.1 & 8 & 22.2 \\
\hline Yapılmadı & 23 & 63.9 & 28 & 77.8 \\
\hline \multicolumn{5}{|l|}{ Hareketlilik durumu } \\
\hline Mobil & 31 & 86.1 & 34 & 94.4 \\
\hline İmmobil & 5 & 13.9 & 2 & 5.6 \\
\hline \multicolumn{5}{|c|}{ Yoğun bakımda kalma durumu } \\
\hline Evet & 5 & 13.9 & 4 & 11.1 \\
\hline Hayır & 31 & 86.1 & 32 & 88.9 \\
\hline
\end{tabular}

lendi. Yaşıı hastalarda uygulanan anestezi türünün ameliyat sonrası bilişsel fonksiyonlarda etkili olduğu $(p=0.04)$, genel anestezi sonrası 1. günde bilişsel fonksiyonlarda anlamlı düşme olurken, bölgesel anestezi uygulanan hastalarda her üç zaman diliminde de bilişsel fonksiyonların normal sınırlar içerisinde olduğu belirlendi (Tablo 5).

Ameliyat öncesi ve sonrası biyokimya sonuçları karşılaştırıldığında; ameliyat öncesi ve sonrası dönemde sodyum, bilirubin, kreatinin değerlerinin normal ( $p>0.05$ ); albümin değerlerinin ameliyat öncesi ve ameliyat sonrası 
Tablo 5: Hastaların cerrahi girişim sürecine ilişkin özellikleri ile MMT puan ortalamalarının karşılaştırılması

\begin{tabular}{|c|c|c|c|c|}
\hline & & $\begin{array}{l}\text { Ameliyat öncesi } \\
\text { Mean } \pm \text { SD }\end{array}$ & $\begin{array}{c}\text { Ameliyat sonrası 1.gün } \\
\text { Mean } \pm \text { SD }\end{array}$ & $\begin{array}{c}\text { Ameliyat sonrası 3.gün } \\
\text { Mean } \pm \text { SD }\end{array}$ \\
\hline \multicolumn{2}{|l|}{ Cerrahi süresi (3.18 \pm 1.52 saat) } & $27.66 \pm 3.20$ & $21.77 \pm 8.00$ & $24.91 \pm 4.49$ \\
\hline$r$ & $\mathrm{p}$ & 0.20 & -0.29 & 0.21 \\
\hline \multirow{2}{*}{ Cerrahi yöntemi } & Açık & \multirow{2}{*}{$\begin{array}{l}27.21 \pm 3.69 \\
28.46 \pm 1.98\end{array}$} & \multirow{2}{*}{$\begin{array}{l}21.04 \pm 8.32 \\
23.07 \pm 7.55\end{array}$} & \multirow{2}{*}{$\begin{array}{l}24.60 \pm 5.24 \\
25.46 \pm 2.81\end{array}$} \\
\hline & Kapalı & & & \\
\hline Z & $\mathrm{p}$ & -0.66 & -0.84 & -0.13 \\
\hline \multirow[t]{2}{*}{ Anestezinin tipi } & Genel & \multirow{2}{*}{$\begin{array}{l}27.16 \pm 3.50 \\
28.16 \pm 2.89\end{array}$} & $19.61 \pm 8.56$ & $23.94 \pm 5.10$ \\
\hline & Bölgesel & & $23.94 \pm 6.97$ & $25.88 \pm 3.67$ \\
\hline $\mathbf{Z}$ & p & $-0.77 \quad 0.43$ & $-2.030 .04^{*}$ & -1.110 .26 \\
\hline \multirow[t]{3}{*}{ Cerrahi tipi } & Ortopedik cerrahi & $27.47 \pm 3.45$ & $20.63 \pm 9.97$ & $25.52 \pm 4.22$ \\
\hline & Ürolojik cerrahi & $27.90 \pm 2.37$ & $24.20 \pm 4.02$ & $24.80 \pm 4.77$ \\
\hline & Genel cerrahi & $27.85 \pm 3.93$ & $21.42 \pm 6.10$ & $23.42 \pm 5.12$ \\
\hline KW & $\mathrm{p}$ & $0.52 \quad 0.76$ & $0.69 \quad 0.70$ & $1.07 \quad 0.58$ \\
\hline \multirow[t]{2}{*}{ Kan transfüzyonu } & Yapıldı & \multirow{2}{*}{$\begin{array}{l}27.87 \pm 3.64 \\
27.60 \pm 3.14\end{array}$} & \multirow{2}{*}{$\begin{array}{l}19.75 \pm 9.36 \\
22.35 \pm 7.67\end{array}$} & $24.50 \pm 4.14$ \\
\hline & Yapılmadı & & & $25.03 \pm 4.65$ \\
\hline Z & $\mathrm{p}$ & $0.47 \quad 0.63$ & $\begin{array}{ll}-1.08 & 0.27\end{array}$ & $-0.51 \quad 0.65$ \\
\hline \multirow[t]{2}{*}{ Ameliyat öncesi hareket durumu } & Mobil & \multirow{2}{*}{$\begin{array}{l}28.12 \pm 2.59 \\
24.80 \pm 5.26\end{array}$} & \multirow{2}{*}{$\begin{array}{c}22.51 \pm 7.39 \\
17.20 \pm 10.98\end{array}$} & $25.19 \pm 4.27$ \\
\hline & İmmobil & & & $23.20 \pm 5.93$ \\
\hline $\mathbf{Z}$ & $\mathrm{p}$ & $-1.36 \quad 0.17$ & $-1.30 \quad 0.19$ & $-0.75 \quad 0.44$ \\
\hline Ameliyat sonrası hareket durumu & Mobil & $27.55 \pm 3.26$ & $21.47 \pm 8.12$ & $24.64 \pm 4.47$ \\
\hline & İmmobil & 29.5 & $27.00 \pm 2.82$ & 29.5 \\
\hline Z & $\mathrm{p}$ & $-0.52 \quad 0.59$ & $-1.14 \quad 0.25$ & $-1.63 \quad 0.10$ \\
\hline Ameliyat öncesi yoğun bakımda & Evet & $27.40 \pm 4.77$ & $24.40 \pm 4.82$ & $25.20 \pm 5.16$ \\
\hline kalma & Hayır & $27.70 \pm 2.99$ & $21.35 \pm 8.38$ & $24.87 \pm 4.47$ \\
\hline $\mathbf{Z}$ & $\mathrm{p}$ & $-0.19 \quad 0.84$ & $-0.80 \quad 0.42$ & $-0.20 \quad 0.83$ \\
\hline Ameliyat sonrası & Evet & $29.50 \pm 1.00$ & $26.25 \pm 2.87$ & $27.25 \pm 2.75$ \\
\hline yoğun bakımda kalma & Hayır & $27.43 \pm 3.32$ & $21.21 \pm 8.28$ & $24.62 \pm 4.61$ \\
\hline $\mathbf{Z}$ & $\mathrm{p}$ & $-1.17 \quad 0.24$ & $-1.49 \quad 0.13$ & $\begin{array}{ll}-1.03 \quad 0.29\end{array}$ \\
\hline
\end{tabular}

${ }^{*} p<0.05$

Tablo 6: Hastaların ameliyat öncesi ve sonrası biyokimya test sonuçları

\begin{tabular}{|c|c|c|c|c|}
\hline & $\begin{array}{l}\text { Ameliyat Öncesi } \\
\text { Mean } \pm \text { SD }\end{array}$ & $\begin{array}{l}\text { Ameliyat Sonrası } \\
\text { Mean } \pm \text { SD }\end{array}$ & $\mathrm{t}$ & $\mathrm{p}$ \\
\hline \multicolumn{5}{|l|}{ Biyokimya sonuçları } \\
\hline Sodyum (mEq/L) & $139.44 \pm 2.44$ & $135.86 \pm 11.98$ & 1,75 & 0.08 \\
\hline Hematokrit (\%) & $35.39 \pm 4.24$ & $34.24 \pm 4.32$ & 1.75 & 0.08 \\
\hline Total bilirubin (mg/dl) & $0.66 \pm 0.47$ & $0.56 \pm 0.14$ & 1.28 & 0.20 \\
\hline Albümin (g/dl) & $2.91 \pm 1.70$ & $2.91 \pm 1.59$ & 0.03 & 0.97 \\
\hline Kreatinin (mg/dl) & $0.96 \pm 0.20$ & $0.97 \pm 0.29$ & 0.13 & 0.89 \\
\hline Açlık kan glikozu (mg/dl) & $119.47 \pm 32.59$ & $127.47 \pm 33.85$ & -2.42 & $0.02^{*}$ \\
\hline
\end{tabular}

${ }^{*} \mathrm{p}<0.05$

dönemde düşük olduğu ( $p>0.05$ ) saptandı. Kan glikozu değerlerinin ise ameliyat öncesi normal iken istatistiksel anlamlı şekilde ameliyat sonrası normal değerin biraz üstünde olduğu belirlendi ( $p=0.02$ ). (Tablo 6). Hastaların biyokimya test sonuçları ile ameliyat öncesi, ameliyat sonrası 1. ve 3. günlerdeki MMT puan ortalamaları karşılaştırıldığında istatistiksel anlamlı farklılık saptanmadı ( $p>0.05$ ).

Tablo 7 incelendiğinde; hastaların yaş ortalamaları ile ameliyat öncesi $(p=0.004)$ ve ameliyat sonrası 3 . günde $(p=0.004)$ ölçülen test sonuçları arasında negatif yönde istatistiksel anlamlı ilişki olduğu, hastaların yaşı yükseldikçe testten daha düşük puan aldıkları saptandı. Aynı tabloda, kadınların ameliyat sonrası 1. gün $(\mathrm{p}=0.008)$ ve 3 . gün ( $p=0.001$ ) MMT aldıkları puanların erkeklere göre ista- tistiksel anlamlı şekilde daha düşük olduğu bulundu. Diğer bireysel özellikler ile ameliyat öncesi, ameliyat sonrası 1. gün ve 3. gün MMT sonuçlarında istatistiksel anlamIı bir farklılık saptanmadı (Tablo 7).

\section{TARTIŞMA}

Cerrahi girişim geçiren yaşlı hastalarda bilişsel fonksiyon değişikliklerinin ve nedenlerinin incelendiği bu çalışmada, ameliyat öncesi dönemde hastaların tamamına yakınının bilişsel fonksiyonlarının normal olduğu saptandı. Ancak hastaların yarısında cerrahi girişim sonrası 1. günde bilişsel fonksiyonlarında bozulma olduğu, 3. günde de hala hastaların üçte birinde bilişsel bozuklukların 
Tablo 7: Hastaların bireysel özellikleri ile MMT puan ortalamalarının karşılaştırılması

\begin{tabular}{|c|c|c|c|c|}
\hline & & $\begin{array}{l}\text { Ameliyat öncesi } \\
\text { Mean } \pm \text { SD }\end{array}$ & $\begin{array}{l}\text { Ameliyat sonrası 1.gün } \\
\text { Mean } \pm \text { SD }\end{array}$ & $\begin{array}{c}\text { Ameliyat sonrası 3.gün } \\
\text { Mean } \pm S D\end{array}$ \\
\hline Yaş $(68.58 \pm 5.33)$ & & $27.66 \pm 3.20$ & $21.77 \pm 8.00$ & $24.91 \pm 4.49$ \\
\hline$r$ & $\mathrm{p}$ & $\begin{array}{ll}-0.46 & 0.00^{*}\end{array}$ & $\begin{array}{ll}-0.09 & 0.58\end{array}$ & $-0.46 \quad 0.00^{*}$ \\
\hline Cinsiyet & Erkek & $29.31 \pm 1.49$ & $23.52 \pm 8.73$ & $27.42 \pm 2.89$ \\
\hline $\mathbf{Z}$ & $\mathrm{p}$ & $-3.49 \quad 0.00^{*}$ & $-2.67 \quad 0.00^{*}$ & $-3.47 \quad 0.00^{*}$ \\
\hline Medeni durum & Evli & $27.85 \pm 3.00$ & $21.91 \pm 7.88$ & $25.08 \pm 4.12$ \\
\hline \multirow[t]{2}{*}{ Sigara } & Evet & 30.00 & $26.00 \pm 5.65$ & $28.50 \pm 2.12$ \\
\hline & Hayır & $27.52 \pm 3.24$ & $21.52 \pm 8.11$ & $24.70 \pm 4.52$ \\
\hline Z & $\mathrm{p}$ & -1.27 & -0.83 & -1.25 \\
\hline \multirow[t]{2}{*}{ Yaşadığı kişiler } & Yalnız & 25.00 & 21.00 & 18.00 \\
\hline & Eşi ve çocukları ile & $27.74 \pm 3.22$ & $21.80 \pm 8.12$ & $25.11 \pm 4.39$ \\
\hline Z & $\mathrm{p}$ & -1.15 & -0.67 & -1.40 \\
\hline \multirow{2}{*}{ Gece uyku alışkanlığı } & 6-8 saat & $27.40 \pm 3.68$ & $21.45 \pm 8.46$ & $24.77 \pm 4.58$ \\
\hline & 8 saatten fazla & 30.00 & $20.80 \pm 12.27$ & $28.60 \pm 2.07$ \\
\hline KW & $\mathrm{p}$ & $5.97 \quad 0.05$ & $0.14 \quad 0.93$ & 0.07 \\
\hline
\end{tabular}

${ }^{*} \mathrm{p}<0.05$

devam ettiği belirlendi. Bu sonuç istatistiksel olarak da anlamlı bulundu. Elde edilen bu bulgu, yaşlı hastaların cerrahi girişimin neden olduğu stresle baş etmede güçlük yaşadıklarının göstergesi olarak yorumlanabilir. Literatürdede, yaşın ilerlemesi ile birlikte bilişsel fonksiyonlarda gerileme olduğu ve ileri yaşın ameliyat sonrası bilişsel bozukluk gelişimi açısından büyük risk oluşturduğu vurgulanmaktadır $(12,20)$. Ucuzal ve arkadaşlarının çalışmasında, bu güncel çalışma bulgusu ile benzer şekilde, ileri yaştaki hastaların, ameliyat öncesi ile ameliyat sonrası 1. ve 3. günlerde, MMT'den daha düşük puan aldıkları bildirilmiştir (2). Kotekar ve arkadaşları da, ameliyat sonrası 3. günde hastaların \%12'sinde bilişsel fonksiyon bozukluğunun devam ettiğini saptamışlardır (12).

Araştırmada, hastaların büyük çoğunluğunun ameliyat sonrası analjezik kullandıkları saptandı. Analjezik türü incelendiğinde yaşlı hastalarda opioid analjeziklerin reçete edildiği bulundu. Opioid kullanımının yaşlı hastalarda istatistiksel olarak anlamlı olmamasına karşın bilişsel fonksiyon değişikliklerine neden olduğu belirlendi. Ameliyat öncesi, ameliyat sonrası 1. ve 3. günlerde MMT puan ortalamalarının opioid kullanan hastalarda diğer analjezik türlerini kullananlardan daha düşük olduğu bulundu. Ameliyat sonrası bilişsel fonksiyon değişikliklerinin nedenleri tam olarak kanıtlanamamıştır. Ortaya atılan teoriler, ameliyat sonrası kullanılan opioid analjeziklerin etkili olduğunu savunmaktadırlar $(3,8,20)$. Yapılan çalış- malarda da ameliyat sonrası kullanılan opioidlerin yaşlı hastaların bilişsel fonksiyonlarında istatistiksel anlamlı değişiklik oluşturmadığı bildirilmiştir $(3,5,8)$.

Günümüzde, cerrahi girişimler çok ileri yaşlardaki hastalara rahatlıkla uygulanabilmektedir. Buna karşın, normal yaşlanma sürecinin ve hastalıkların neden olduğu değişikliklerin, cerrahi girişimin akut ya da elektif olmasının, cerrahi girişimin şeklinin, cerrahi girişimin süresinin, cerrahi girişimin süresine bağlı kan kayıplarının, ayağa kalkma sürecinin ameliyat sonrası dönemde komplikasyon gelişimini artırırı̆ı ve bilişsel fonksiyonlarda bozukluğa yol açtığı bildirilmektedir $(2,4,5,12,13,20)$. Bu güncel araştırmada, cerrahi girişimin süresi, kan transfüzyonu uygulanması, hastanın hareketlilik durumu ile ameliyat öncesi ve ameliyat sonrası yapılan izlemlerde alınan MMT puan ortalamaları arasında istatistiksel anlamlı bir ilişki saptanmadı, ancak MMT puanlarının ameliyat öncesi değere göre düştüğü belirlendi. Bu durumun ameliyat öncesi ve sonrası kan transfüzyonu yapılan, hareketsiz olan hasta sayısının çok az olmasının ve geçirilen cerrahi girişim süresinin çok uzun olmamasının bir sonucu olduğu düşünülmektedir.

Araştırmada üç farklı uygulanan cerrahi girişim tipinin ameliyat sonrası yaşlı hastaların bilişsel fonksiyonlarında anlamlı değişiklik oluşturmamakla birlikte; ürolojik cerrahi girişim geçiren hastalarda her üç zamanda da MMT puan ortalamalarının normal sınırlarda olduğu, ortopedik 
cerrah girişim geçiren hastalarda ise ameliyat sonrası 1 . günde düştüğü ancak 3. günde normale döndüğü, genel cerrahi hastalarında ise düşen MMT puan ortalamalarının 3. günde henüz normale dönmediği saptandı. Bu bulgular önceki araştırma bulgularını desteklemektedir. Linstedt ve arkadaşları farklı cerrahi tipleri uygulanan hastalarda ameliyat sonrası bilişsel fonksiyon değişikliklerinin benzer oranlarda (\%10) azaldığını belirtmişlerdir (21). Evered ve arkadaşları da kardiyak cerrahi, ortopedik cerrahi ve koroner anjiyografi uygulanan hastalarda yaptıkları çalışmalarında cerrahinin tipi ile bilişsel fonksiyon bozukluğunun oluşması arasında anlamlı farklılık saptamamışlardır (10).

Araştırma kapsamına alınan yaşlı hastalarda uygulanan anestezinin türünün ameliyat sonrası 1.günde bilişsel fonksiyonları anlamlı şekilde etkilediği, genel anestezi uygulanan hastalarda MMT puan ortalamalarının anlamlı şekilde düştüğü, bölgesel anestezi uygulananlarda ise normal sınırlarda olduğu belirlendi. Önceki çalışmalarda da bu araştırma bulgusuna paralel olarak, bölgesel anestezi uygulanan yaşlı hastalarda ameliyat sonrası bilişsel fonksiyonlarda bozulma olmadığı genel anestezinin bilişsel fonksiyonları daha sık olumsuz etkilediği bildirilmiştir $(17,22)$.

Araştırmaya alınan yaşlıların ameliyat öncesi ve sonrası biyokimya sonuçlarındaki sodyum, hematokrit, total bilirubin, albümin, kreatinin değerlerinde istatistiksel açıdan anlamlı bir farklılık saptanmadı. Elde edilen biyokimya test sonuçlarının hastaların bilişsel fonksiyon değişikliklerinde etkili olmadığı saptandı. Önceki araştırmalarda bu araştırma bulgusundan farklı sonuçlar elde edilmiştir. Bu güncel araştırma bulgusu; sodyum, total bilirubin ve kreatinin değerlerinde de istatistiksel anlamlı farklılık bulunmayan önceki araştırma bulguları ile benzerdir $(13,23)$. Ancak, Akarsu ve arkadaşlarının ameliyat öncesi ve ameliyat sonrası kreatinin ve albümin değerlerinde, Robinson ve arkadaşlarının hematokrit ve albümin değerlerinde istatistiksel anlamlı farklılık saptadıkları çalışma bulgularına ters düşmektedir $(13,23)$. Litaker ve arkadaşları da biyokimyasal değişikliklerin özellikle narkotik kullanımı ile kombine olduğunda bilişsel fonksiyonlarda anlamlı değişiklikler yaptığını belirtmişlerdir (24).

Araştırmada hastaların yaş ortalamaları ile ameliyat öncesi ve ameliyat sonrası 3. gündeki MMT puan ortalamaları arasında negatif yönde istatistiksel anlamlı ilişki saptandı. Hastaların ameliyat öncesi MMT puan ortalaması normal sınırlar içindeyken, ameliyat sonrası 1 . ve 3 . günde düşüş gözlendi. İlerleyen yaş ile birlikte ilaç kullanımında artış, kullanılan ilaçlar arasındaki etkileşimler, yalnızlık hissi, duyusal algılarda azalma ameliyat sonrası bilişsel fonksiyon değişikliklerinde etkili olabilmektedir $(24,25)$. Litaker ve arkadaşları da bu güncel araştırma bulgusuna benzer şekilde, 70 yaş ve üzerindeki yaşlı hastalar ile ameliyat sonrası deliryum arasında ilişki olduğunu bildirmiştir (24).

Bu araştırmada, cinsiyetin ameliyat sonrası bilişsel fonksiyon bozukluklarında istatistiksel anlamlı şekilde risk faktörü olduğu belirlendi. Araştırmada, erkeklerin ameliyat öncesi dönemde kadın hastalara göre MMT puan ortalamaları istatistiksel anlamlı şekilde daha yüksekti. Ameliyat sonrası dönemde de MMT puanlarındaki düşüş istatistiksel anlamlı şekilde kadınlarda erkeklerden daha yüksekti. Bu sonuç, çok sayıdaki önceki araştırma bulguları ile paralellik göstermektedir (26-30). Beynin organizasyonunun gelişmesinde ve aktivasyonunda önemli role sahip olan östrojen gibi cinsiyet hormonlarlnın yaşlanmaya bağlı kadınlarda azalmasının bilişsel fonksiyonları olumsuz etkilediğini bildiren çalışmalar güncel çalıma bulgusunu doğrulamaktadır (31-33).

Hastaların ekonomik durumlarına bakıldığında geliri giderinden az olan hastaların MMT toplam değerleri ameliyat sonrası 1. günde geliri giderlerine eşit olan hastalara göre daha fazla gerileme gösterdiği belirlenmiştir. Gönen ve arkadaşları ile Diker ve arkadaşlarının araştırmalarında da bilişsel değişikliğin görülme sıklığı gelir durumu giderden az olan hastalarda daha çok olduğu bulgusu, bu güncel araştırmanın verilerini destekler niteliktedir (27).

Türkiye'de yaşıı nüfusu toplam nüfusun \%1.6'sı kadar olduğundan bu çalışma küçük bir örneklem büyüklüğü ile sınırlandı. Çalışmanın tek bir hastanede yapılmış olması da bu çalışmanın bir kısıtlılığıdır. Bu bağlamda çalışmanın bulgularının genelleştirilmesi mümkün değildir. Hastanenin hasta ile görüşülebilecek özel bir odası olmadığından görüşmeler hasta odasında gerçekleştirilmiş olması çalışmanın diğer bir kısıtlığıdır. Bu nedenle sessiz bir ortam için akşam saatlerinde görüşme yapılmaya çalışılmıştır.

Araştırmanın bulguları, yaşlı hastaların ameliyat sonrası bilişsel fonksiyonlarında anlamlı bozulma olduğunu göstermiştir. Ayrıca cerrahi girişim geçirme yaşının artışı ile bilişsel fonksiyon bozukluklarının ilişkili olduğu, uygulanan genel anestezinin ameliyat sonrası bilişsel fonksiyonları anlamlı şekilde etkilediği ve kadın olmanın bir risk faktörü olduğu sonucuna varılmıştır. Bu sonuçlara göre; cerrahi girişim geçirecek yaşlı hastaların kabulü sırasında bilişsel fonksiyonlarını değerlendiren mental durumun tanılanmasının yapılması, risk altında olan yaş- 
Iıların belirlenmesi, bilişsel fonksiyon bozukluğuna bağlı komplikasyonları önlemek üzere hemşirelik bakım planı doğrultusunda hemşirelik bakımın sağlanması önerilmektedir.

\section{KAYNAKLAR}

1. Aygin D, Aslan F, Cengiz H. Yaşlı cerrahi hastasında ameliyat sonrası erken dönem. Akad Geriatri 2012; 4: 12-17.

2. Ucuzal M, Akyolcu N. Yaşlı hastalarda ameliyat sonrası bilişsel değişiklikler. Turkish J Geriatrics 2008; 11: 119-127.

3. Claude $\mathrm{M}$, Yvan $\mathrm{P}$, Gilles $\mathrm{B}$, et al. Comparison of intravenous or epidural patient-controlled analgesia in the elderly after major abdominal surgery. Anesthesiol 2000; 92: 433-441.

4. Damuleviciene G, Lesauskaite V, Macijauskiene J. Postoperative cognitive dysfunction of older surgical patients. Medicina (Kaunas) 2010; 46: 169-175.

5. Krenk L, Kehlet H, Bæk Hansen T, Solgaard S, Soballe K, Rasmussen LS. Cognitive dysfunction after fast-track hip and knee replacement. Anesth Analg 2014; 118: 1034-1040.

6. Dahn J, Eckert S, Oster M, et al. Cognitive functions and cerebral oxygenation of older patients after general and regional anaesthesia. Anaesthesist 2003; 52: 596-605.

7. Erden A, Uzun Ş, Turgut H, Aypar Ü. Yaşlı hastalarda anestezi. Akademik Geriatri Dergisi 2009; 1: 162-166.

8. Fong HK, Sands LP, Leung JM. The role of postoperative analgesia in delirium and cognitive decline in elderly patients: a systematic review. Anesth Analg 2006; 102: 1255-1266.

9. Scott JE, Mathias JL, Kneebone AC. Postoperative Cognitive dysfunction after total joint arthroplasty in the elderly: a metaanalysis. J Arthroplasty 2014; 29: 261-267.

10. Evered L, Scott DA, Silbert B, Maruff P. Postoperative cognitive dysfunction is independent of type of surgery and anesthetic. Anesth Anal. 2011; 112: 1179-1185.

11. Jin F, Chung F. Minimizing perioperative adverse events in the elderly. Br J Anesthesia 2001; 87: 608-624.

12. Kotekar N, Kuruvilla CS, Murthy V. Post-operative cognitive dysfunction in the elderly: A prospective clinical study. Indian J Anesth 2014; 58: 263-268.

13. Akarsu Ayazoğlu T, Tür H, Bolat C, Özkaynak I, Candan M. Yașlılarda kardiyak cerrahi sonrası yoğun bakımda deliryum prevelansı ve risk faktörleri. J Experiment Clin Med 2012; 29: 101-107.

14. Aydoğmuş $M$, Tükenmez B. Spinal anestezi altında yapılan açık prostatektomi sonrası gelişen postoperatif deliryum: Olgu sunumu. Firat Tıp Dergisi 2012; 17: 57-59.

15. Deren S, Ün C, Temur í, ve ark. Postoperatif erken dönemdeki deliryuma yaklaşım. Türk Anest Rean Der Dergisi 2010; 38: 388-394.

16. Lou MF, Dai YT, Huang GS, Yu PJ. Postoperative cognitive changes among older Taiwanese patients. J Clin Nurs 2003; 12: 579-588.

17. Başmergen T. Transüretral rezeksiyon operasyonları sonrası kognitif fonksiyonların değerlendirilmesi. Trakya Üniversitesi Tıp Fakültesi Anesteziyoloji ve Reanimasyon Anabilim Dalı, Uzmanlık Tezi, Edirne, 2010.
18. Folstein MF, Folstein SE, McHugh PR. Mini-Mental State: a practical method for grading the cognitive state of patients for the clinician. J Psychiatr Res 1975; 12: 189-198.

19. Güngen C, Ertan T, Eker E, Yaşar R, Engin F. Standardize mini mental test'in türk toplumunda hafif demans tanısında geçerlik ve güvenilirliği. Türk Psikiyatri Dergisi 2002; 13: 273-281.

20. Girrad NJ. Preoperative care nursing manegement. In: Lewis MF, Heitkemper MM, Dirksen RS (Eds). Medical surgical nursing assesment and management of clinical problems. Vol 1, 6th ed. Mosby; Philadelphia, 2004 ; pp. 374-412.

21. Linstedt U, Meyer $\mathrm{O}$, Kropp $\mathrm{P}$, Berkau A, Tapp E, Zenz $\mathrm{M}$. Serum concentration of S-100 protein in assessment of cognitive dysfunction after general anesthesia in different types of surgery. Acta Anaesthesiol Scand 2002; 46: 384-389.

22. Papaioannou A, Fraidakis O, Michaloudis D, Balalis C, Askitopoulou $\mathrm{H}$. The impact of the type of anaesthesia on cognitive status and delirium during the first postoperative days in elderly patients. Eur J Anaesthesiol 2005; 22: 492-499.

23. Robinson T, Raeburn C, Tran Z, Angles E, Brenner L, Moss M Postoperative delirium in the elderly. Ann Surg 2009; 249: 173-178.

24. Litaker D, Locala J, Franco K, Bronson DL, Tannous Z. Preoperative risk factors for postoperative delirium. Gen Hosp Psychiatry 2001; 23: 84-89.

25. Üstek S, Boran M. Multipl travmalı hastada postoperatif gelişen deliryum. Ege Tıp Dergisi 2010; 49: 67-70.

26. Çuhadar D, Sertbaş G, Tutkun H. Huzurevinde yaşayan yaşılıarın bilişsel işlev ve günlük yaşam etkinliği düzeyleri. Anatolian J Psychiatry 2006; 7: 232-239.

27. Gönen S, Küçükgüçlü Ö, Yener G. Hastanede yatan yaşlı bireylerde demansla ilişkili olabilecek işlevsel-bilişsel bozukluk sıklığının incelenmesi. J Neurol Sci (Turkish) 2010; 27: 446-456.

28. Guijarro R, San Roman C, Gomez-Huelgas G, et al. Impact of dementia on hospitalization. Neuroepidemiology 2010; 35: 101108.

29. Natalwala A, Potluri R, Uppal H, Heun R. Reason for hospital admissions in dementia patients in Birmingham, UK, during 20022007. Dement Geriatr Cogn Disord 2008; 26: 499-505.

30. Schmidt $R$, Kienbacher $E$, Benke $T$, et al. Sex differences in Alzheimer's disease. Neuropsychiatry 2008; 22: 1-15.

31. Xing Y, Qin W, Li F, Jia XF, Jia J. Associations between sex hormones and cognitive and neuropsychiatric manifestations in vascular dementia (VaD). Arch Gerontol Geriatr 2013; 56: 85-90.

32. Yaffe K, Lui LY, Grady D, Cauley J, Kramer J, Cummings SR. Cognitive decline in women in relation to non-protein-bound oestradiol concentrations. Lancet 2000; 356: 708-712.

33. Yaffe K, Lui LY, Zmuda J, Cauley J. Sex hormones and cognitive function in older men. J Am Geriatr Soc 2002; 50: 707-712. 